\title{
Religiosity in Charles Dickens' Novel a Christmas Carol Through Genetic Structural Method
}

\author{
Robert Juni Tua Sitio, Yumna Rasyid, Aceng Rahmat
}

\begin{abstract}
This study aims to examine comprehensively the meaning and the existence of religiosity in Charles Dickens' Novel A Christmas Carol. It is a qualitative research using a structural genetic approach. The data were collected from the text of the novel and analyzed through a content analysis. The results of this study are as follows: (1) Autonomous structures of the novel such plot, character, setting and theme have a coherent as a whole and are interconnected to describe the problem of religiosity in the novel A Christmas Carol which indicate transformation of religiosity such as religious belief, religious practices and religious values to improve the quality of human life. (2) Social structure of English Society in Industrial Revolution indicates its significance in describing social context of English society in the novel of A Christmas Carol. Such as, the problem of population density, low labor salaries, the high cost of daily living in the City of London, and the degradation of religiosity in the British Society. (3) The author's world view indicates the need of change of man's religiosity through his or her affection of social and religious experience to recover the meaning and the application of religiosity in human life especially in the aspect of solidarity. religiosity based on structural genetics, the autonomous structure of the novel A Christmas Carol, the social structure of British society during the Industrial Revolution, and the worldview of the author has a unified whole to prove that there is a homologous relationship between social reality, especially religions of British society during the Industrial Revolution
\end{abstract}

Index Terms: Religiosity, Dickens' A Christmas Carol, Genetic Structural approach

\section{INTRODUCTION}

Dickens was an outspoken English writer who effectively employed his fiction to critisize economic, social and moral abuses in the Victorian era. He showed compassion and emphaty towards the vulnerable and disadventaged segments of the English society, and contributed to several important social reforms (1) Most of novels presented the problem of poverty as a serious social and economic burden of English sociiety of the late 19 th century (2) Besides social, moral and economic issues, Dickens novels also presented the problem of religiosity that occurred in British society during the Industrial Revolution especially in his five christmas Novels. Novel A Christmas Carol published in 1843 becomes the most popular one until now. In Dickens' A Christmas Carol, he critized on issues of degradation of religiosity of British Society in 19 th century.

Revised Manuscript Received on September 22, 2019

Robert Juni Tua Sitio, Language Education at Universitas Negeri Jakarta.robertjuni_pb11s3@mahasiswa.unj.ac.id

Yumna Rasyid, Language Education at Universitas Negeri Jakarta.

Aceng Rahmat, Language Education at Universitas Negeri Jakarta.
The issue of religiosity in British society was one of the crucial problems to be studied until nowadays. This can be proven in many recent studies, namely: First, (3) examined religious constellation about the nature and existence of life after death according to main Characters' beliefs in Dickens' Christmas Novels and British society in the 19th century. Second, (4) examined similar issues in "Pay Back novel: Debt Shadow Side of Wealth" and "A Christmas Carol" especially about religiosity and morality of British society in 21st and 19th century regarding human tragedy in the poor who suffer from hunger on the one hand, and the greed of the rich on the other. Third, (5) examined the practice of moral and religious hypocrisy of the upper class of British society of the late Victorian England in play "Oscar Wilde's The Importance of Being Earnest." The three previous studies proved that religious issues during Industrial revolution needed to be exposed in order that people might get moral and religious message from the sequent evets in the novels. (6) stated that until nowadays, various scholars have made claims about literature's potential to evoke empathy and self-reflection, which would eventually lead to more pro-social behavior.

In this research, the aim of the study is to examine the meaning and the existence of religiosity in Charles Dickens' novel A Christmas Carol through genetic structural approach. Using this approach, the study of religiosity is viewed in three terms, they are: outonomous structure of the novel, social structure of the novel, and author's worldview.

\section{LITERATURE REVIEW}

According to (7) There is no 'objective' definition of religion since definitions of religions are always subjectively related to either confessional or naturalist mindsets. Definition of religion always reflects the geographical, cultural, historical, economic and political context. Religious ideas are distributed unevenly among the individuals of a faith group so the definition must be properly formulated in order to observe the required purpose at hand, such as academic, legal, civic, political purpose. In addition, (8) stated that the assessment of religiosity issues had several approaches based on scientific disciplines. For example, a theologian would address religiosity from the view point of faith. (9-11) While religious educators could focus on orthodoxy and belief (12, 13) Psychologist might choose to address the dimensions of devotion, holiness, and piousness, (14-17). 
Then, sociologist would consider the concept of religiosity to include church membership, church attendance, belief acceptance, doctrinal knowledge, and living the faith. $(15,18$, 19). In addition, the assessment of religiosity approach could be based on religion, sects, and cults. Such as: Christian religiosity (20-23) Islamic religiosity. Buddhist religiosity (23)

According to (24) dimensions of religiosity consist of: a) dimensions of religious belief (dogmatic), about the nature of God, heaven, and hell; b) dimensions of religious practices such as performing ritual of religious practices or worship; c) dimension of religious experience which indicates closeness to God, believe his/her prayer is granted, d) dimensions of religious knowledge, which indicates one's understanding and knowledge of his/her religion; and e) dimension of religious consequential, which indicates consistency of individual behavior in accordance to his/her religion. In this research, the study of religiosity is divided into three dimensions, they are: religious belief, religious practice, and religious values (25). Hence the object of this study is Dickens'novel A Christmas Carol, so the context of this study must be ascociated to Christian religiosity. Consequently, the indicators of the three dimensions of religiosity must follow the rules of Christianity. First, the indicators of religious belief are as follow: (1) believe in God, the Father Almighty Creator of universe and everything in it, believe in Jesus Christ as the Savior, believe in the Holy Spirit as the Preserver, (2) believe the Word of God and all God's promises as written in the Bible, (3) believe that man has sinned against the Lord through human's mind, desires or passions, words and deeds, (4) believe that God curse and punish all sin since the fruit of sin is death. Because of the love of God and His true mercy, he promises all believers eternal life, 5) Believe that man is saved only by the free gift of God's grace (26)

Second, Indicators of religious practice were based on personal will in doing religious practices. From statements above, indicators of religious practice were as follow: 1) keep holiness of Sabbath/ Sunday and religious holidays and invite other Christians, and invite other Christians to do so, 2) have private meditation to pray or read the Bible, 3) always surrender to God in joy and sorrow, 4) be polite in words and deeds, 5) do not lie toward others or tell lies under oath, 6) help one another, 7) respect the elders. 8) be honest in gaining and owning all property. 8) forgive others' wrong doing by not holding grudges or injuring others (murder, abortion) or commit suicide, 9) be faithful in marriage, 10) Maintain living things and environment well as God's creation.(27) Third, Indicator of religious values include personal experiences that generate happiness, admiration, and other good inner impressions. The indicators of religious values were: 1) feel deep inner peace and harmony by God's mercy, 2) feel secure about strength and comfort in the God's presence that all burdens are enlightened by the help of God, 3) believe that God has better plan and certain purpose for one's life. 4) feel that man is precious before God, 5) feel gratitude to the Lord for the beauty of all his (28) creations (29-31)

\section{METHODOLOGY/MATERIALS}

This research used content analysis method to explore, analyze, and give meaning to spesific message of the text within its context (32). Content analysis is a method to analyze the contents both explicitly (text) and implicitly (context) regarding the true meaning of the text (33) Specifically, content analysis is intended for the analysis of a written text content and classified based on the problem then interpreted so that a comprehensive understanding is obtained on the issues under study. The scope of analysis were: theoretical studies, data analysis, and discussion (34)

The study of religiosity in Dickens' A Christmas Carol through structural genetic approach consists of three sub focuses, namely: (1) Religiosity is viewed from the autonomous structure of the novel. (2) Religiosity is viewed from the social structure of the British Society during the Industrial Revolution which contributed in proses of creating the novel A Christmas Carol. (3) Religiosity is viewed from the author's worldview $(19,35)(36)$

The data of this research were in the form of words, phrases, and sentences. Data were obtained through analysis of outonomous structure of the novel (such as theme, plot, character, and setting), Social structures of the novel, and author's world view relating to religiosity with three dimensions of religiosity, namely religious beliefs, religious practices and religious values in the novel A Christmas Carol. The primary data source of the research was Charles Dickens' novel A Christmas Carol by using Arthur Racham's illustrations and published by Chapman and Hall in England in 1843, then reprinted by J.B. Lippincott in Philadelphia. Meanwhile, secondary data were all information and theories about religiosity, history of British society during industrial revolution, Charles Dickens' biography from various publicized sources and documents.

\section{RESULTS AND FINDINGS}

The result of this study was based on textual evidence of the novel which were used as research data to be described and analyzed according to the focus / sub focus of the study, including: (1) The study of religiosity based on the autonomous structure of A Christmas Carol; (2) The study of religiosity based on the social structure of the novel; (3) The study of religiosity based on the aothor's worldview of the novel. Based on the research findings, the descriptions and the discussions of this research are as follows:

\section{A. The study of religiosity based on autonomous structures of the novel}

The Study of religiosity based on autonomous structures such as plot, characters, setting and theme have a coherent whole and are interconnected to describe the problem of religiosity in the novel A Christmas Carol. The study of religiosity in terms of the novel storyline proves that the problems of the main character's religiosity are elaborately and chronologically described. At the beginning of the story, Scrooge was a materialist, selfish, ignorant of others, and anti-Christmas. 
Next Scrooge experienced a series of conflicts with the character of Ghost of Jacob Marley and three Christmas Spirits. The conflict event changed Scrooge's attitude to be a good person. Then, he loved Alfred's family and helped Bob Cratchit's family, and other people. He went to church and celebrated Christmas. At the end of the story, Scrooge felt peacefulness and happiness in his life.

The study of religiosity based on the main character, Scrooge showed a degradation of religiosity such as: greed, materialism, no matter what the surrounding environment, did not care about Christmas. In this occasion,(37) stated that British society that belonged to rich people during industrial revolution tended to be selfish, materialist, dishonest, arrogant and did not like religious matters. they tended to measure happiness with the standard of property ownership. In addition, (5) stated that there was discrepancy between the inherent Christian identity in the British society during the industrial revolution with religious behavior in everyday life. For this reason, Dickens as the author of the novel treated Scrooge in special treatment.The change in Scrooge's religiosity occurred after he had experienced several conflicts with character of Marley's ghost and the three Christmas Spirits. The totality of Scrooge's religiosity transformations can be proven in three dimensions of religiosity, they are: (1) The dimension of religious belief indicates that Scrooge believed in life after death, he believed that human being was sinner through the mind, desire or lust, word and deed. (2) The dimension of religious practice indicates that Scrooge worshiped and celebrated Christmas. He prayed and thanked God for the lesson he had experienced. Scrooge became polite in words and deeds, he sincerely helped others. (3) The dimension of religious values indicates that Scrooge always felt happiness and peacefulness. Scrooge felt that human being was valuable before God. In this occasion, (28) stated that the level of religiosity of a person affected the level of happiness and anxiety. This was influenced by the availability of value guidelines, religious services, and exemplary attitudes that could resolve anxiety or depression over the problems faced by every person.

The study of religiosity based on the setting of the place, time and social have a unified as a whole illustrating the problem of religiosity in the novel A Christmas Carol. The setting of place of the story was London, England. Location of the story originated from the counting house of Scrooge \& Marley. The location indicated the place of economic activities. Furthermore, location of Scrooge house indicated several blocks from his counting house. Scrooge lived in old chamber consisted of gloomy suite rooms. These two places indicated Scrooge as a rich man. The description of the atmosphere of darkness and the silence of the house and the yard all night indicated that Scrooge was a solitary man and did not care about his social surroundings. The use of London as a business and metropolitan center indicated that the people of London were always busy with daily economic activities. People of London became an industrial society that calculated profits in every opportunity and they were obsessive to gain prosperity or wealth. This situation degdradated religious orientation of Industrious society especially in London during industrial revolution.

Setting of time in the novel A Christmas Carol did not use specific dates, months and years but the novel used the term Christmas. This story started at three o'clock in the afternoon on Christmas Eve which told the atmosphere of the cold city of London and the heavy snowfall. At night, the atmosphere was cooler, and darker over the house Scrooge. This atmosphere depicted Scrooge's solitary life, and did not rejoice in celebrating Christmas. On the night of Christmas Eve, Scrooge had a dream and in conflict with the Marley's ghost and the Three Spirits of Christmas. The second day started in the morning on Christmas Day. The picture of the atmosphere of a sunny day and the sound of echoing bells echoing reflected changes in the atmosphere of the city. Similarly, Scrooge committed as an old good man. he went to church, gave Christmas gifts to Bob Cratchits' family, visited Alfred's house, gave donations to the poor. The end of the story of the novel took place the day after Christmas (Christmas Boxing). Scrooge raised Bob Cratchit's salary and helped Tiny Tim's to get good health care. Scrooge spoke politely and greeted other people respectfully. The more Scrooge did good deeds, the happier Scrooge felt. In this occasion, (38) stated that a higher level of happiness on Christmas is a Christmas experience with family, giving and receiving Christmas gifts as a feeling of gratitude and joy for Christmas.

The main ideas in the novel contained facts about religiosity issues that dominated a series of dialogues and conflicts experienced by Scrooge with other characters from the beginning to the end of the story, resulted that the theme of the novel A Christmas Carol is " transformation of religiosity to improve the quality of human life"

\section{B. The study of religiosity based on social structure of the novel}

The study of religiosity based on the social structure of British society during the Industrial Revolution proves that social conditions are homologous with the problem of religiosity in the novel A Christmas Carol. This homologous description can be proven in the similarity of the social conditions of British society that faced three problems, namely: the problem of population density, low labor salaries, and the high cost of daily living in the City of London. According to (39) the density of London population was due to the urbanization of the villagers to seek Jobs in London. Industrial Revolution created more and more job opportunities in the city. Many business owners used this opportunity to offer low wagesfor there were large number of workers in London at that time. Because labor costs were low, workers suffered from food shortages, health problems and poor environmental sanitation.

To overcome this problem, officials of the charity tried to raise funds at Christmas. However, the effort was less successful because the middle class British community lacked social care. Dickens showed compassion and sympathy towards the lower-class British society for they suffered most in the midst of unjust economic and social condition. 
He described the difficulty of improving the lives of poor people without the solidarity of the rich. So he criticized the secular lifestyle of the rich because they had neglected the living condition of the poor. Dickens also criticized religious practices which were considered less relevant in addressing the social life of the community. Dickens observation on social background of industrial society focused his satirical religiosity portraits on social ethical perspective of solidarity with those who suffered during Industrial Revolution.

\section{The study of religiosity based on author's worldview}

Religiosity based on the author's worldview in the novel A Christmas Carol illustrated character of the British industrial society who had rational and logical principles that prioritized empirical evidence which had had an impact on the degradation of belief such as the existence of life after death (heaven and hell). In this occassion, (40) stated that the items in such a pattern of beliefs, preferences, hopes, fears, and actions of a person - hang together rationally. Consequently, a person's propositional attitudes and actions may be said to bear internal, rational relations to one another. A particular propositional attitude is what it is by virtue of its rational relations to other attitudes and actions. In A Christmas Carol, Dickens described fears, hope, christian belief, and actions, especially about belief in the existence of the Spirit and the consequences of the good and bad qualities of human religiosity affecting the life after death. Scrooge observed the suffering of Marley's ghost and the ghosts of guilty governments in the life after death. Scrooge heard those ghosts' sad lament. Then Scrooge observed that the misery of each ghost was bound by chains and everything they used in committing a crime. Dickens believed that the attitude of human religiosity such as Scrooge was determined by three considerations, they were: first, the disclosure of good experiences or memories of the past created feelings of emotion and empathy. Conversely, the disclosure of memories in the form of mistakes and regrets gave a negative reaction in the form of anger, revenge and hatred. Dickens proved his view on the story of Scrooge's travelling with The Spirit of Christmas past to several places in Scrooge's past life. Scrooge was touched and shed tears in memory of his childhood when he was in school. Instead, Scrooge was angry and disappointed at himself when he saw the events of his bitter memories in his youth. Scrooge prioritized ambition to acquire wealth rather than to care Belle so that Belle broke her engagement with Scrooge. Second, anticipatory knowledge and actions in the present time were influenced by social care and social interaction. Dickens proved his view on the story of Scrooge's travelling with Spirits of Christmas Present to various places. Scrooge got moral lesson from his travelling that made him understand the real problem of his surroundings. Then he showed compassion and sympathy to the poor. Third, hope for a better future. Dickens proved his view on the story of Scrooge's travelling with the Spirit of Christmas Future to reveal the shadow of Tiny Tim's death and Scrooge's death. In that occasion, Scrooge saw no one cared about his body. Furthermore, the grave was left neglected. The description of the two tragic deaths in the future made Scrooge repent. He became religious person. he celebrated Christmas every year, he cared and helped people

sincerely, he was polite in words and deeds. The more Scrooge did good deeds, the happier he felt.

\section{CONCLUSION}

Autonomous structures of the novel such plot, character, setting and theme have a coherent whole and are interconnected to describe the problem of religiosity in the novel A Christmas Carol which indicate transformation of religiosity such as religious belief, religious practices and religious values to improve the quality of human life. Religiosity based on social structure of English Society in Industrial Revolution shows its significance in describing social context of English society in the novel of A Christmas Carol. Such as, the problem of population density, low labor salaries, the high cost of daily living in London, and the degradation of religiosity in British Society. Dickens viewed that it was difficult to improve the life of poor people without the solidarity of the rich. Dickens recommended that the solution of the problems was transformation of man's religiosity through his or her affection of social and religious experience to recover the meaning and the application of religiosity in human life especially in the aspect of solidarity.

\section{ACKNOWLEDGEMENT}

The researcher presents his sincerely appreciation for promotor and co-promotor for their suggestion, guidance and correction toward this article. The researcher gratefully thanks to all postgarduate lecturers of Language Eduaction in Universitas Negeri Jakarta

\section{REFERENCES}

1. Mashair Mohammed Jumaa Oshi YOB. The Conditions of England as Reflected by Dickens' Social Novel. SUST Journal of Humanities. 2015;16(1):7.

2. Yazdan Bakhsh Gholami AHJ. A Social Study of Poverty in Charles Dickens's Hard Times, Bleak House and Oliver Twist. J Nov Appl Sci,. 2014;3(6):7.

3. Roy ND. The Christmas Boooks: a non-Dickensian Paradise of Fantasy, Magic and Supernatural. Ruphkata Journal an Interdisiplinary Studies in Humanities. 2012;4(1).

4. Rousselot E. A Christmas Carol and Global Economy: The Neo-Victorian Debt to the Nineteenth Century. Neo-Victorian Studies. 2012;5(2):25.

5. Hazra S. Oscar Wilde's The Importance Of Being Earnest: A Critique Of The Victorian Society. INDIAN JOURNAL OF RESEARCH $2013 ; 2(1)$.

6. Koopmans R. Religious Fundamentalism and Hostility against Out-groups: A Comparison of Muslims and Christians in Western Europe. Journal of Ethnic and Migration Studies. 2014;41(1):33-57.

7. Landmann A. The Study of Religion - Thoughts on Approaches. Journal of Religious Culture. 2013(177).

8. HOLDCROFT B. WHAT IS RELIGIOSITY? A Journal of Inquiry and Practice. 2006;10(1):15.

9. John T. Jost CBH, Brian A. Nosek, Erin P. Hennes, Chadly Stern, Samuel D. Gosling, Jesse Graham. Belief in a Just God (and a Just Society): A System Justification Perspective on Religious Ideology. Journal of Theoretical and Philosophical Psychology. 2013:27.

10. Démuthová S. Fear of death in relation to religiosity in adults. GRANT journal. 2014:5.

11. Wade C.Rowatt LAK. Two Dimensions Of Attachment to God and Their Relation to Affect, Religiosity and Personality Construcs. JOURNAL FOR THE SCIENTIFIC STUDY OF RELIGION $2002 ; 41(4): 15$ 
12. Meteyard JD, Andersen KL, Marx E. Exploring the Relationship between Differentiation of Self and Religious Questing in Students from Two Faith-based Colleges. Pastoral Psychology. 2011;61(3):333-42.

13. G. L. Forward ND, Heather Miche, Danica Sandberg. The Effects of Communication, Religiosity, and Organizational Support on Student Commitment at a Church-Related University. Human Communication. 2009;12(1).

14. Zuroff DC. Was Gordon Allport a Trait Theorist. Journal of Personality and Social Psychology. 1986;51(5).

15. Stapleton M. An Investigation of Moral Development: the Effect of Religiosity on Kohlbergian Moral Reasoning. Student Psychology Journal. 2013:14.

16. Renate Ysseldyk KM, Hymie Anisman. Religiosity as Identity: Toward an Understanding of Religion From a Social Identity Perspective. Personality and Social Physycology Review. 2010:11.

17. BART NEYRINCK WL, MAARTEN VANSTEENKISTE, BART SOENENS. Updating Allport's and Batson's Framework of Religious Orientations: A Reevaluation from the Perspective of Self-Determination Theory and Wulff's Social Cognitive Model. Journal for the Scientific Study of Religion. 2010;49(3):14.

18. Ahlin L. BACK TO THE CLASSICS - THE RELATION BETWEEN SOCIAL EXPERIENCES AND RELIGIOSITY. Nordic Journal of Religion and Society. 2010;23(1):25

19. Heidi E. Stolz JAO, Teri M. Henke, Brian K. Barber. Adolescent Religiosity and Psychosocial Functioning: Investigating the Roles of Religious Tradition, National-Ethnic Group, and Gender. Child Development Research. 2013.

20. Ebrahim Khodadady NB. Construct Validation of a Modified Religious Orientation Scale within an Islamic Context. International Journal of Business and Social Science. 2012;3(11):10.

21. Salleh MS. Religiosity in Development: A Theoretical Construct of an Islamic-Based Development. International Journal of Humanities and Social Science. 2012;2(14):9.

22. DICK HOUTMAN PH. Christian Religiosity and New Age Spirituality: A Cross-Cultural Comparison. JOURNAL FOR THE SCIENTIFIC STUDY OF RELIGION. 2006.

23. Dinkins L. Toward Contextualized Creeds A Perpective From Buddhist Thailand. International Journal of Frontier Missiology. 2010;27(1):5.

24. F R. HANDBOOK OF THE PSYCHOLOGY OF RELIGION AND SPIRITUALITY. RAYMOND F. PALOUTZIAN CLP, editor. New York THE GUILFORD PRESS; 2005.

25. Noris P. Sacred and Secular. Michigan USA: Cambridge University Press; 2004.

26. Pontoppidan E. Explanation of Luther's Small Catechism. Belfour E, editor. Chicago USA: Anderson and Lawsons; 2018.

27. Hayward RD, Kemmelmeier M. Weber Revisited. Journal of Cross-Cultural Psychology. 2011;42(8):1406-20.

28. Warren S, Bruce A. Stevens, Stuart Cathcart. Religiosity and happiness: A comparison of the happiness levels between the religious and the nonreligious. The Journal of Happiness \& Well-Being. 2016;4(1):18.

29. Park J, Roh S, Yeo Y. Religiosity, social support, and life satisfaction among elderly Korean immigrants. Gerontologist. 2012;52(5):641-9.

30. Saroglou V, Delpierre V, Dernelle R. Values and religiosity: a meta-analysis of studies using Schwartz's model. Personality and Individual Differences. 2004;37(4):721-34.

31. Peter C. Hil LEM. Measuring Religiousness and Spirituality: Issues, Existing Measures, and the Implications for Education and Wellbeing. International Handbook of Education for Spirituality, Care and Wellbeing.17.

32. Knoblauch H. A Companion to QUALITATIVE RESEARCH Edited by Uwe Flick, Ernst von Kardorff and Ines Steinke. London: Sage Publication; 2001.

33. Franzosi R. Content Analysis. An Introduction to its Methodology. The British Journal of Sociology. 2017.

34. Mayring P. Qualitative content analysis: theoretical foundation, basic procedures and software solution. Qualitative content analysis: theoretical foundation, basic procedures and software solution. 2014.

35. Ezzat Molla Ebrahimi MS. Sociological Critique of Baha Tāher's East of the Palms. Journal of World Sociopolitical Studies. 2017:23.

36. GOLDMANN L. CULTURAL CREATION IN MODERN SOCIETY. OXFORD: BASIL BLACKWELL •; 1971.

37. BOUZIANE K. Materialism versus Human Values in the Victorian Novels: The Case of Great Expectations and Wuthering Heights. Arab World English Journal (AWEJ. 2015:7.
38. TIM KASSER KMS. WHAT MAKES FOR A MERRY CHRISTMAS? Journal of Happiness Studies. 2002;3.

39. OLADJEHOU BB. Charles Dickens' analysis of the French Revolution in a Tale of Two Cities: A critical study. International Journal of Humanities, Social Sciences and Education. 2017;4(4).

40. David H. Finkelstein. On The Distinction Betwen Consciuos and Unconsciuos States Of Mind. American Philosophical Quarterly. 1999;36(2):23 